\title{
Shaping the perception of African conflicts through framing: A case study of the African diasporic press in the UK
}

\begin{abstract}
Framing studies consistently conclude that the international news media represent African conflicts negatively and stereotypically. Owing to their focus on media content, however, most framing studies fail to examine the dynamic relationship between journalists' cognitive role (what they say they do) and their practice role (what they actually do). Using parallel content analysis, this study compares what African diaspora journalists write about African conflicts with what they say about them. The analysis reveals that they show a preference for a factual style and a governing frame, and less preference for a judgmental style, which aligns with what they say, and a slight preference for background context which marginally aligns with what they say. However, low newsroom budgets and advertising revenue could undermine their attempts to de-Westernise the portrayal of African conflicts.
\end{abstract}

Keywords: framing, diaspora journalists, African diasporic press, African conflicts, methodological frameworks, role perception

\section{Introduction}

According to the Global Conflict Tracker (2017), there are ten conflict hotspots in Africa including Nigeria, Mali, Democratic Republic of Congo, Egypt, Libya, Central African Republic, Burundi, Sudan and Somalia. The media have an important role to play in reporting these conflicts, but scholars have criticised the international news media for giving prominence to 'fatal frames' (Kothari 2010), focussed on destruction, war tactics, or tribalism, and giving less prominence to 'conflict resolution frames' (Armentia and Marin 2018), which focus on peace building and economic growth. The dominance of 'fatal frames' suggest that journalists evaluate Africa based on socially accepted norms and/or empirical viewpoints which lead to 'a selective view of what happens in the world' (Harcup 2004: 30). Nyamnjoh (2016: 35) argues that when journalists are 'groomed in institutions and societies in which these stereotypical representations of Africa are widespread....it is difficult to extricate oneself enough to cultivate the sensitivities and sensibilities necessary to report and write about Africa the way Africans would'. Stories about African conflicts are more likely to make the front page than stories about economic growth. A World Economic Forum report notes that 'the continent achieved average real annual GDP growth of 5.4\% between 2000 and 2010, adding \$78 billion annually to GDP' (World Economic Forum, 2016). Such positive news can only make the front page when journalists project a balanced view of Africa and adopt a 'factual style' which focuses 'on events, actions or current situations, with an emphasis on the "what", "who", "when" and "where" questions, generally without judgment-based adjectives or adverbs' (Bastien 2018: 7).

Through framing analysis, it is possible to discern patterns in the treatment of stories about people and places and in the organisation of an 'idea or storyline that provides meaning to an unfolding strip of events, weaving a connection among them' (Gamson and Modigliani 1989: 3). Moreover, framing analysis helps to identify the devices which denote the constitutive elements of news frames (Capella and Jamieson 1997: 45; D'Angelo 2002: 881), including the 'problem definition, causal interpretation, moral evaluation and/or treatment recommendation' (Entman 1993: 55). However, framing studies fail to provide a deep insight into the relationship between what journalists write (a practice role) and what they say (a cognitive role) about 
African conflicts. The practice role orientations 'materialise in the process of news production' and are 'enacted in the context of anticipated or actual discursive interaction with sources, markets, and publics' (Hanitzsch and Vos 2017: 126). In other words, it concerns how journalists' professional role, situation and context influence the way they write. The cognitive role refers to 'the institutional values, attitudes, and beliefs individual journalists embrace as a result of their socialization' (2017: 125). It is informed and reinforced by professional norms of objectivity, public service, ethics, autonomy, and immediacy (Deuze 2005: 447). Cognitive and practice roles are enacted through the negotiation that 'occurs at the point of contact of frame and an individual's prior knowledge' (D'Angelo 2002: 875). Framing research helps us to study the relationship between these roles because it brings together both contextual setting and cognitive preconceptions, thus it includes the "content of frames which amalgamates textual items (words and images) with the contextual treatment that they receive from framing devices' and the news frames that 'interact with the cognitive and social behaviours that they have shaped in the first place' (D'Angelo 2002: 873).

Framing research on the portrayal of African conflicts in the Western media has focused solely on media content (a product of journalists' practice role) with occasional interviews with media practitioners. These studies have consistently found that a negative portrayal of Africa is prevalent, albeit with a lower intensity than in previous decades, and that prominence is given to African conflicts over political, economic and socio-cultural issues. Bunce et al. (2016: 1), for example, observe that 'research from the 1970s through to the 1990s demonstrated that international representations of Africa were narrow, laden with stereotypes, and highly dependent on Cold War frames and portrayals of an impoverished, often savage, "other". Other scholars caution that 'keywords, visual and stereotyped images, catchphrases, moral appeals and underlying lines of reasoning' (Gamson et al. 1992) could 'subtly convey meaning and preferred readings of a subject' (Fornaciari 2011: 225). For example, Kothari (2010: 209) found that 'war, disease, and famine symbolise Africa in news reports by the US media'. The decision to use particular framing devices and news sources is influenced by professional norms, situation and context. This may explain why the Western media portrayal of African conflicts has been found to rely 'almost entirely on non-African sources, depicting Africa as a timeless and placeless realm of "tribal" conflict' (Myers et al. 1996: 21).

Framing scholars note that the media adopt strategic or issue-specific frames by selecting certain aspects of an issue in order to cue a specific response and to explain who is responsible (Iyengar 1991). The strategic frame seems to be the preferred frame by Western media as evident in the prominence of certain aspects noted in literature to cue a specific response to African conflicts including:

civil war in Africa involves fierce, tribally based fighting...that two sides in the conflict commit atrocities, lack discipline...that their leaders want power at all costs, are reluctant to negotiate...that the supply of western food aid is often prevented by civil war and/or siphoned off by corrupt African officials; that ordinary civilians get killed, displaced...that Westerners are in danger and are told to leave... and that peace talks are initiated by an outside party or brokered by the church, but they usually fail because of squabbles between opposing parties over trivial issues.

(Brookes 1995: 467)

The effect of using a strategic frame is that it distracts readers from the substance of African conflicts and peace initiatives. In contrast, a generic or governing frame typically describes structural aspects and features of news that can apply across different topics or issues (Matthes 
2009: 360). It tends to cue readers to consider the big picture, including problems and solutions, conflict resolution, and peace building initiatives. Scholars have found that Western media gives less prominence to governing frames in news stories of African conflicts, thereby entrenching 'western racism, intolerance..., and indifference to their struggles' (Myers et al. 1996: 43) and militating 'against cross-cultural comparisons regarding certain social phenomena which obtained in but are not peculiar to Africa' (Mafeje 1993: 919). The missing link in these framing studies on African conflicts is their failure to consider the relationship between what journalists write and what they say about these conflicts. By focusing on this relationship, this study will fill a gap in the framing literature.

\section{Overview of the African diasporic press}

The African diasporic press is an appropriate case study because it is usually overlooked in empirical research. This diasporic press caters for Africans who are resident in the UK either temporarily or permanently. There was a marked increase in the inflow of Africans to the UK in the mid-1980s because of political and economic instabilities. During this period, their interests shifted from an 'education focus' to an 'economic focus' as they embarked on developing their professional careers, providing for their immediate family and supporting their extended families back home through regular remittances (Ogunyemi 2012). But the negative stereotypes of black people, the marginalisation of their voices and the lack of culturally relevant information in the mainstream media spurred the growth of African diaspora press in the 1990s.

The diasporic newspapers selected for this study were among the first to fill the gap in the media market and have demonstrated their resilience by staying afloat for many years. The Trumpet is a fortnightly newspaper established in 1995; Africa Today is a monthly magazine also established in 1995; and African Voice is a weekly newspaper established in 2001. Their mission statements reveal some common traits: they provide a platform for Africans to tell their own stories, to voice their opinions on civic issues in the diaspora and host country, and to portray a positive image of Africa and African people. Their journalistic approach is discernible from their news agenda. For example, the Trumpet claims to be 'the voice of Africans worldwide and...to highlight the difficulties and problems of the community worldwide' (Trumpet, 2017a). Africa Today aims 'to produce a high standard news magazine for Africa. And to give an authentic African view of Africa' (Africa Today, 2017a). And African Voice wants to "cover home news, evaluate UK government policies as it affects the communities and present the African perspective to breaking news' (African Voice, 2017a). 
Notably, their business model is sole ownership with all the risk that it entails in terms of investment, decision making, professional standards and social responsibility. The editors are not members of the National Union of Journalists because, as a small scale operations, they struggle to meet the financial obligations of membership and of employing NUJ members. They are not members of the Foreign Press Association (FPA), with the exception of the editor of Africa Today. He recalled that he came to the UK in 1978 as a correspondent and joined the Commonwealth Press Union in conjunction with the FPA. He was proud to state that he is one of the oldest members on the register having carried the card for over 38 years. He affirmed that he is guided by its codes of practice (interview with the editor of Africa Today, 7 August 2017).

The editors come from diverse professional backgrounds. The editor of Africa Today started his journalism career at the Daily Sketch newspaper in Ibadan, Nigeria. He has been practising journalism the longest, marking his 41 years in the profession by posting on Facebook: 'my first published front-page lead story with my first published by-line, as a professional journalist. It was the front-page lead story of the Ibadan-based Daily Sketch edition of July 8,1977 , and my coming of age and the turning point in my long career as a newspaper reporter' (Soyinka, 2017). The editors of African Voice and Trumpet newspapers worked in aviation and economics respectively before turning to journalism because of their passion for writing and their inclination to correct the misrepresentation of Africa and African people in the UK.

In terms of readership, the Trumpet targets the fast growing and vibrant community of Africans who have made UK their home. Designed for Africans of all sexes, age groups, income levels, and educational backgrounds at home and abroad, the newspaper takes into consideration the major market segments within the community (Trumpet, 2017b). The editor of African Voice notes that the newspaper serves the following demographics: $45 \%$ first generation immigrants, $40 \%$ British born second generation, 5\% short/medium stay visitors and holidaymakers from the African continent, and 10\% British based non-Africans with an interest in African affairs. And in terms of demographic, $50 \%$ of readers are West Africans, $30 \%$ are Southern Africans, 10\% are East and Central Africans and 10\% are North Africans (interview with the editor of African Voice, 11 August, 2017). While the editor of Africa Today notes 'we don't actually publish for Africans as such and we don't distribute in African shops. You can find us in WH Smith. We appeal to businesses and friends of Africa. That is why we published in London with the advantages of quality printing and international airports to get 
our distribution to various parts of the world' (interview with the editor of Africa Today, 7 August 2017).

\section{Research Design}

The aim of this study is to compare what the editors say about African conflicts (cognitive role) with what they write about them (practice role). Hence, the following questions were posed: do the editors use judgmental and/or factual styles in news stories of African conflicts? What framing devices do the editors use in news stories of African conflicts? Do editors provide historical background context in news stories of African conflicts?

The questions were examined using parallel content analysis (PCA). This methodological approach is well established in the literature. For instance, Neuman (1989) combined media content analysis and a public opinion survey to study the impact of mass communication. Althaus et al. (2001) used PCA to study the relationship between different types of media content, that is, the New York Times Index entries, lead paragraphs and headlines of the same stories. And Bastien (2018) used it to consider the dynamic relationship between politics and journalism. In this study, PCA enables the researcher to combine the interview and media content data to examine the relationship between them in the coverage of African conflicts, thereby filling a gap in framing research. Hence, parallel content analysis offers a multi-perspective approach on the phenomenon of news framing of African conflicts whilst also engaging with the methodological issues raised through the use of framing analysis.

The researcher interviewed three editors of African diasporic newspapers (they all bear the title of publisher/editor-in-chief). Interviews were conducted by telephone for between 45 and 60mins and the interviewees gave their consent for the interviews to be recorded. The interview with the editor of African Today magazine, Mr Kayode Soyinka, was conducted on 7 August 2017 (Africa Today 2017a); with the editor of Trumpet newspaper, Mr Femi Okutubo, on 9 August, 2017 (Trumpet, 2017a); and with the editor of African Voice newspaper, Mr Mike Abiola, on 11 August, 2017 (African Voice, 2017b). The discussion focused on their opinions on judgmental and factual styles, on cultural knowledge of Africa, on preferred framing devices and on the challenges of covering African conflicts.

African Voice and Trumpet newspapers were selected for textual analysis because their frequency of publication covers the entire period of analysis. However, Africa Today magazine was excluded from the textual analysis because the editor confirmed that it hardly covers 
conflicts due to its focus on African businesses and international businesses operating in Africa. This readership profile 'dictates the kind of stories it covers such as the International Telecommunications Union and the World Petroleum Congress' (interview with the editor of Africa Today, 7 August 2017). The magazine editor's perspective was included in the interview data because of the similarities in the news agenda and the mindset of these editors in their portrayal of Africa. The period of analysis started in April 2014 because it marked the time Boko Haram snatched the Chibok school girls in north-eastern Nigeria and the analysis ended in August 2017. All news stories about African conflicts found within the period of study will be analysed (comments, editorials, letters to the editors and opinion features were not included). A total of 74 full length news reports were found on the websites of the African Voice and the Trumpet newspapers and analysed. These stories were about conflicts in Nigeria, South Sudan, Egypt, Kenya, Democratic Republic of Congo, Somalia, Central African Republic, Libya, Ethiopia and Uganda.

In analysing the stories, the researcher generated a code for judgmental style, factual style, strategic frame and governing frame from claims and findings in previous studies (Iyengar 1991; Brookes 1995; Myers et al, 1996; D’Angelo 2002; Kothari 2010; Dekavalla 2016; Bunce 2016; Armentia \& Marin 2018; Bastien 2018). To classify stories under a judgmental style, the researcher looked for references to judgment-based words such as warlords, savage, and barbaric. To classify stories under a factual style, the researcher looked for references to news writing formula, that is, "what", "who", "when" and "where" questions. To classify stories under a background context, the researcher looked for references to knowledge/historical account of Africa. To classify stories under a strategic framing, the researcher looked for references to the combatants (personality, opinions), their motives and strategies. Finally, to classify stories under a governing frame, the researcher looked for references to conflict resolution and peace building initiatives.

\section{Data analysis}

\section{Judgmental style in African conflict stories}

Bunce (2016) notes that international representations of Africa were narrow, laden with stereotypes which suggest an adoption of a judgmental style promoting an impression that conflict is escalating with no end in sight. In contrast, the African diasporic press avoids judgmental style as shown in Table 1 with $4 \%$. 


\begin{tabular}{|l|l|l|l|l|l|}
\hline $\begin{array}{l}\text { African } \\
\text { diasporic } \\
\text { press }\end{array}$ & $\begin{array}{l}\text { Judgmental } \\
\text { style }\end{array}$ & $\begin{array}{l}\text { Factual } \\
\text { style }\end{array}$ & $\begin{array}{l}\text { Background } \\
\text { context }\end{array}$ & $\begin{array}{l}\text { Strategic } \\
\text { frame }\end{array}$ & $\begin{array}{l}\text { Governing } \\
\text { frame }\end{array}$ \\
\hline Trumpet & $2(3 \%)$ & $42(56 \%)$ & $14(19 \%)$ & $5(7 \%)$ & $32(43 \%)$ \\
\hline $\begin{array}{l}\text { African } \\
\text { Voice }\end{array}$ & $1(1 \%)$ & $29(37 \%)$ & $13(17 \%)$ & $2(3 \%)$ & $27(36 \%)$ \\
\hline Total & $\mathbf{4 \%}$ & $\mathbf{9 3 \%}$ & $\mathbf{3 6 \%}$ & $\mathbf{1 0 \%}$ & $\mathbf{7 9 \%}$ \\
\hline
\end{tabular}

Table 1: Styles and frames in African conflict stories

The data suggests they denounce the atrocity of conflict by using judgmental words such as 'unending internecine wars', 'military warlords', 'inhumanity' and 'notorious warlords' as seen in the story of conflict in DRC:

'The Democratic Republic of Congo's seemingly unending internecine wars has thrown up as much military warlords as may be imagined if the experiences of Liberia and Sierra Leone are anything to go by. The replication of inhumanity in these contexts is better not imagined. A most notorious warlord, Ntabo Ntaberi Sheka, who has been declared, wanted for alleged crimes against humanity, surrendered to U.N. peacekeepers on Wednesday, the U.N. mission in Congo (MONUSCO) has said' (African Voice 2017c).

The use of a judgmental style has prompted some scholars to accuse the western media of using 'stereotyping of the other, and negative headlines about Islam and Muslims, to sell newspapers' (Yusah'u 2012:105). But the editors of African diasporic press argue that they do not adopt a judgmental style for commercial reasons. Rather, 'we make editorial decisions when there is a major conflict as to whether it should be reported as an inside story or cover story' (interview with the editor of Africa Today, 7 August 2017). They also avoid a judgmental style by assessing 'the fairness of the words used to describe African conflicts' (interview with the editor of Trumpet, 9 August 2017). This implies that they are suspicious of judgment based adjectives or adverbs that trivialise African conflicts and demean African people. This is evident in the comment 'that the use of tribalism and ethnicity distract attention from the real causes of African conflicts which are corruption and greed among political elites' (interview with the editor of African Voice, 11 August, 2017).

The editors, however, acknowledged that the use of judgmental style 'can be different from organisation to organisation' (interview with the editor of Africa Today, 7 August 2017) 
which is why some Western media have a more negative outlook on Africa than others. The editors recognise that their African correspondents may adopt a judgmental style when reporting conflict involving their ethnic group. But they trust their correspondents to avoid a judgmental style because they are authoritative and experienced journalists (interview with the editor of Africa Today, 7 August 2017). Nevertheless, they mitigate the use of judgmental style by cross-checking reports received against reports from other sources such as CNN and IRIN. Overall, the data provides evidence that what they say they do (cognitive role) matches what they really do (practice role).

\section{Factual style in African conflicts stories}

In rejecting judgmental style, the African diasporic press embraces a factual style which is a hallmark of professional journalism, especially in news writing. The writing formula, labelled 5 Ws i.e. 'what, where, who, when and why', helps journalists to include the most relevant aspects of the event in the story. It helps them to present the story as it is, thereby enabling readers to reach their own conclusion. The editors say they apply factual style and argue that 'we concentrate on the facts and leave the judgment to readers' (interview with the editor of Trumpet, 9 August 2017). The textual analysis data reveals a match between their cognitive role and their practice role because the factual style has the highest percentage at $93 \%$ as seen in Table 1. For example, a story about bomb blast in Abuja, Nigeria focused on 'what', 'where' and 'who':

'A bomb blast at a crowded bus park in Nyanya on the outskirts of Nigeria's capital Abuja has left 71 people dead and 124 injured according to Abbas Idris - Head of the Abuja Emergency Relief Agency' (Trumpet, 2014c, p.1).

This factual style is also evident in the story about terrorism in Nigeria that 'Nigerian terrorist group Boko Haram reportedly kidnapped at least 20 women in Garkin Fulani on Saturday, just five miles away from where over 200 hundred school girls were abducted from their school a little less than two months ago' (Dipeolu, 2014).

Their preference for a factual style implies an attempt to de-Westernise the portrayal of African conflicts. But an over-reliance on a factual style could present a superficial view of African conflicts. To address that, the editors 'try to balance it by presenting the good, the bad and the ugly about Africa and African people' (interview with the editor of Trumpet, 9 August 2017). To illustrate, the African Voice adopts a factual style to publish news about the effects 
of conflict on people by stating that 'the United Nations' director of humanitarian operations has recently returned from Somalia where, he says, more than 850,000 people are in desperate need of food and in crisis and emergency conditions' (Agency Reporter, 2014).

The newspaper also adopts a factual style to publish uplifting news about coping with the after-effects of conflict by stating that 'South Sudan will soon witness a number of investors from Korea coming willingly to invest in diverse natural resources in the country' (Agency Reporter, 2013). While the editors acknowledge that the selection of uplifting stories gives the perception that they are biased towards Africa, they are not apologetic because it aligns with their news agenda to project a positive image of Africa. The news agenda also influence the news values criteria for reporting African conflicts. The preferred criteria are proximity which applies to countries with 'a historical colonial relationship with Britain' (interview with the editor of African Voice, 11 August, 2017) and magnitude which 'takes account of the status of the country' (interview with the editor of Africa Today, 7 August 2017).

But adopting a factual style comes at a cost because the newspapers need to pay correspondents to collect first hand news about the event and use journalists who have native knowledge of the place. Scholars have indicted Western media for sending foreign correspondents who lack knowledge of Africa. Hence, Yusah'u (2012: 105) argues that 'many journalists reporting about Islam and Muslims are ignorant of Islamic and Muslim countries'. The African diasporic editors acknowledge the importance of sending journalists to collect first-hand information by arguing that:

we don't rely on or subscribe to any news agency. We report from the theatre of events. We have journalists on the ground that we give proper briefs to about the theme for the month. They understand they have to talk to people, see the event and report from the venue

(interview with the editor of Africa Today, 7 August 2017).

However, they have limited resources to do this most of the time and, to mitigate that, they cross check news stories of African conflicts against reports from multiple sources such as news agencies, Human Rights Watch, Amnesty International and IRIN.

\section{Framing devices in African conflict stories}


Valkenburg et al (1999) claim that framing affects readers' thought processes. For instance, the use of a strategic frame invokes a feeling of 'chaos', 'instability', and 'death' in the mind of readers. This framing device gives the impression that Africa is a dangerous place to live and visit. The data in Table 1 shows that the use of this frame is low at 10 percent. Such minimal use of strategic frame suggests that the African diasporic press avoids distracting readers from the substance of the conflict. A lexical example is a story headlined 'Another bomb attack hits Abuja' which states that:

a video showing just over 130 of the girls was released at press time by Boko Haram. In the video, the terrorist organisation's leader - Abubakar Shekau said the Christian girls had been converted to Islam. There are indications that the group are demanding release of some of their members in prisons - in exchange for the release of the abducted girls.

(Trumpet 2014d, p. 3).

In contrast, the governing frame invokes a feeling of control, peace and stability in the minds of readers. The data shows that it is a preferred framing device in conflict stories at $79 \%$ as shown in Table 1. A lexical example of governing frame is found in a story headlined 'AU Commission to visit South Sudan' which states that 'at a recent meeting the African Union (AU) Commission of Inquiry revised and firmed up its work plan agreeing on working methods and setting out the activities to be conducted as part of its inquiry into the crisis in South Sudan' (Trumpet 2014e, p.8).

The effect of this framing device is that it helps to garner international support to find a lasting solution to these conflicts. In defending the use of this framing device, the editor of Africa Today magazine argues that, 'sometime ago, we reported the political conflict in Zimbabwe comprehensively because it is an important African country and because it played a prominent role in the liberation struggle in South Africa' (interview with the editor of Africa Today, 7 August 2017). The preponderance of the governing frame is an indication that what the editors say they do matches what they actually do.

\section{Background context in African conflict stories}

The editors' cultural knowledge of Africa gives them an advantage over non-African journalists not only to understand the socio-cultural factors that underpin the conflict but also to negotiate access to combatants. This implies that they can embellish African conflict stories 
with historical facts that can give readers a deep insight into the problem. However, evidence from the data in Table 1, which shows background context at $36 \%$, suggests that the editors have not capitalised on their cultural knowledge of Africa. One would have expected the background context to be as high as $50 \%$ considering their argument that they strive to provide balanced report and the claim that 'we give background and explain and educate the world about the event' (interview with the editor of Africa Today, 7 August 2017).

A lexical example of background context is found in the story headlined 'Nigeria's military claims ceasefire agreed with Boko Haram' which states that 'Boko Haram, which roughly translates to "western education is sinful", has been fighting an insurgency since 2009, with 2000 civilians reportedly killed this year. It seeks to create an Islamic caliphate in the country - especially the Northern part' (Trumpet 2014f, p. 6). From a cognitive role perspective, the editors spoke enthusiastically about their political, cultural and religious knowledge of Africa and how these help them to make sense of African conflicts to their readers. However, this cognitive role is not well reflected in their practice role as seen in Table 1.

\section{Conclusion}

The aim of this study was to examine the relationship between the cognitive and practice roles in the coverage of African conflicts by the African diasporic press. Using parallel content analysis, it found that they show more preference for factual style and governing frame, and less preference for judgmental style which align with what they say, and a slight preference for background context which marginally aligns with what they say. The reason for the latter could be attributed to lack of time and ability to engage in research that would provide rich information to include in conflict stories.

The preference for factual style and governing frame enhances their ability to shift perception from a focus on what is wrong with Africa (judgmental frame) which invokes a feeling of helplessness to a discussion of what can be done to resolve African conflicts (governing frame) which invokes a feeling of hope. From this insight, one could argue that the African diasporic press aims to de-Westernise the representation of African conflicts. However, their ability to continue to diversify perspectives about African conflicts could be undermined by low newsroom budget and advertising revenue. 
Low newsroom budget hinders them to pay for journalists to visit African conflict zones and collect first-hand news. This has far-reaching consequences not just for newsgathering but also for the survival of their publication. The editor of Africa Today reflected on these by stating that 'we have a limit on stories to run per edition. So, we budget per edition. But it is very expensive working on stories including travel cost, accommodation cost and writer's fees' (interview). The editor of Trumpet echoed this sentiment by stating that 'we are constrained on budget to cover news, so we rely on news agencies. We would take on more journalists if we had more funds' (interview).

Low advertising revenue is exacerbated by a lack of patronage from big advertising agencies. One of the consequences of this for the African Voice is that it is 'operating at $30 \%$ capacity'. As a result, the editor said he was unable to send a UK-based Kenyan diaspora journalist to cover the 2017 Kenyan election. The editor noted that although the newspaper mitigates the effects of this by providing immediate coverage and breaking news online, he felt that a lack of resources undermines the newspaper's effort to rival western news media or news agencies and to challenge their ideological lens of Africa (interview). Nevertheless, the editors unanimously agree that the way forward is for black African, mainstream and international businesses to regularly place advertisements in the African diasporic press.

This study thus offers a nuanced understanding of the relationship between cognitive and practice roles than exist in contemporary framing literature. In terms of practice, it reinforces the call to bridge that gap between the wish for increased self-reflection and its actual practice among journalists (Ramaker et al, 2015: 345). In terms of research, it shows that the use of parallel content analysis could enrich framing research especially in understanding the impacts of cognitive role on practice role and vice versa. However, it has some limitations. The researcher did not conduct the study in a newsroom environment because the set-up of some of the diasporic press is not easily amenable to a long period of observation and because journalists work mostly from home as freelancers. Future research should examine the relationship between these roles in different news genres on a wide range of African civic issues across diasporic media platforms through an ethnographic study of the newsroom and research should examine the impacts of practice role on diaspora audiences' perception of Africa. 


\section{References}

Althaus, S. L., Edy, J. A. \& Phalen, P. F. (2001) Using substitutes for full-text news stories in content analysis: Which text is best? American Journal of Political Science 45(3):707 - 723.

Africa Today (2017a) Mission Statement. Retrieved on 21 August, 2017 from (https://www.facebook.com/AfricaTodayMagazine/?pnref=lhc

African Voice (2017a) Mission Statement. Retrieved on 21 August, 2017 from https://www.facebook.com/African-Voice-Newspaper-165633222575/?fref=ts

African Voice (2017b) http://africanvoiceonline.co.uk/

African Voice (2017c) Sheka surrenders to UN. Retrieved on 21 August, 2017 from http://africanvoiceonline.co.uk/sheka-surrenders-un/

Agency Reporter (2014) Urgent aid needed to save starving Somalis. Retrieved on 12 August, 2017 from http://africanvoiceonline.co.uk/urgent-aid-needed-to-save-starving-somalis/

Agency Reporter (2013) Korean Millionaires to Invest in South Sudan. African Voice. Retrieved on 12 August, 2017 from http://africanvoiceonline.co.uk/korean-millionaires-toinvest-in-south-sudan/

Armentia, J. I. \& Marin, F. (2018) How the Spanish press frames obesity: A study of content published by El Pais, La Vanguardia and El Correo in 2015. Journalism. Online First.

Bastien, F. (2018) Using parallel content analysis to measure mediatization of politics: The televised leaders' debates in Canada, 1969 - 2008. Journalism. Online First. DOI:10.1177/1464884917751962.

Brookes, H. J. (1995) Suit, tie and a touch of juju - the ideological construction of Africa: a critical discourse analysis of news on Africa in the British press. Discourse and Society, $6(4): 461-494$.

Bunce, M., Franks, S., and Paterson, C. (Eds) (2016) Introduction. A new Africa's Media Image? In M. Bunce, S. Franks and C. Paterson (eds) Africa's Media Image in the $21^{\text {st }}$ Century, pp. 1 - 13. London: Routledge. 
Bunce, M. (2016) The international news coverage of Africa: beyond the 'single story'. In M. Bunce, S. Franks and C. Paterson (eds) Africa's Media Image in the $21^{\text {st }}$ Century, pp. 17 - 29. London: Routledge.

Cappella, J. N. \& Jamieson K, H. (1997) Spiral of Cynicism: The Press and the Public Good. New York: Oxford University Press.

D'Angelo, P. (2002) News framing as a multiparadigmatic research program: A response to Entman. International Communication Association, 870 - 888.

Dekavalla, M. (2016) Issue and Game Frames in the News: Frame-Building Factors in Television Coverage of the 2014 Scottish Independence Referendum. Journalism, Online First. DOI: $10.1177 / 1464884916674231$.

Deuze, M. (2005) What is journalism? Professional identity and ideology of journalists reconsidered. Journalism, 6(4): $442-464$.

Dipeolu, Y. (2014) Boko Haram kidnap more women. African Voice. Retrieved on 12 August, 2017 from http://africanvoiceonline.co.uk/boko-haram-kidnap-more-women/

Entman, R. M. (1993) Framing: Toward Clarification of a Fractured Paradigm. Journal of Communication 43(4): $51-8$.

Foreign Press Association (2017) via https://www.fpalondon.net/

Fornaciari, F. (2011) Framing the Egyptian Revolution: A content analysis of Al Jazeera English and the BBC, Journal of Arab and Muslim Media Research, 4: $2+3: 223-235$.

Gamson, A. and Modigliani, A. (1989) Media discourse and public opinion on nuclear power: A constructivist approach. American Journal of Sociology, 95(1):1 - 37.

Gamson, W. A., Croteau, D., Hoynes, W. and Sasson, T. (1992) Media Images and the Social Construction of Reality. Annual Review of Sociology, 18:373 - 393.

Global Conflict Tracker (2017) Retrieved on 07 August, 2017 from https://www.cfr.org/global/global-conflict-tracker/p32137\#!/conflict/civil-war-in-south-sudan Hanitzsch, T. \& Vos, T. P. (2017) Journalistic roles and the struggle over institutional identity: The discursive constitution of journalism. Communication Theory, 27, 115 - 135. 
Harcup, T. (2004) Journalism: Principles and Practice. London: Sage.

Iyengar, S. (1991) Is anyone responsible? How television frame political issues. Chicago: University of Chicago Press.

Kothari, A. (2010) The Framing of the Darfur Conflict in the New York Times: 2003 - 2006. Journalism Studies 11(2): 209 - 224.

Mafeje, A. (1993) Tribalism. In R. Krieger (ed) The Oxford Companion to the Politics of the World, pp. 918 - 920. New York: Oxford University Press.

Matthes, J. (2009) What's in a Frame? A Content Analysis of Media Framing Studies in the World's Leading Communication Journals, 1990 - 2005. Journalism and Mass Communication Quarterly, Vol. 86, No. 2: 349 - 367.

Myers, G., Klak, T., \& Koehl, T. (1996) The inscription of difference: News coverage of the conflicts in Rwanda and Bosnia. Political Geography, 15(1): 21 - 46.

National Union of Journalists (2017) via https://www.nuj.org.uk/about/nuj-code/

Neuman, W. R. (1989) Parallel content analysis: Old paradigms and new proposals. In: Comstock, G. (ed.) Public Communication and Behaviour, Vol 2, pp. 199 - 280. San Diego, CA: Academic Press.

Nyamnjoh, F. B. (2016) Reporting and writing Africa in a world of unequal encounters. In M. Bunce, S. Franks and C. Paterson (eds) Africa's Media Image in the $21^{\text {st }}$ Century, pp. 33 - 37. London: Routledge.

Ogunyemi, O. (2012) What newspapers, films and television do Africans living in Britain see and read? The media of the African diaspora. Lewiston, NY: The Edwin Mellen Press.

Ramaker, T., van der Stoep, J., \& Deuze, M. (2015) Reflective Practices for Future Journalism: The Need, the Resistance and the Way Forward. Javnost: The Public, Vol. 22(4): 345 - 361.

Soyinka, K. (2017) First front page byline. Retrieved on 21 August, 2017 from https://www.facebook.com/kayode.soyinka.5

Trumpet (2017a) Mission Statement. Retrieved on 21 August, 2017 from http://trumpetmediagroup.com/about 
Trumpet (2017b) About. Retrieved on 21 August, 2017 from http://trumpetmediagroup.com/about

Trumpet (2014a) Abuja bombed. Vol. 20, No 360, April 16 - 29, p.1. Retrieved on 2 February 2018

from

http://content.yudu.com/Library/A2tqal/TheTrumpetNewspaperI/resources/index.htm?referre $\underline{\mathrm{rUrl}}=$

Trumpet (2014b) Another bomb attack hits Abuja, Vol. 20, No 362, May 14 - 27, p.3. Retrieved $\begin{array}{lllll}\text { on } & 12 & \text { February } & 2018 & \text { from }\end{array}$ http://content.yudu.com/Library/A2v4xe/TheTrumpetNewspaperI/resources/index.htm?referr $\underline{\operatorname{erUrl}}$

Trumpet (2014c) AU Commission to visit South Sudan' Vol. 20, No 360, April 16 - 29, p.8. $\begin{array}{llllll}\text { Retrieved } & \text { on } & 12 & \text { February, } & 2018 & \text { from }\end{array}$ http://content.yudu.com/Library/A2tqal/TheTrumpetNewspaperI/resources/index.htm?referre $\underline{\mathrm{rUrl}}=$

Trumpet (2014d) Nigeria's military claims ceasefire agreed with Boko Haram. Vol. 20, No 374 , Oct 29 - Nov 11, p. 6. Retrieved on 12 February 2018 from

http://content.yudu.com/Library/A38nv6/TheTrumpetNewspaperI/resources/index.htm?referr $\underline{\text { erUrl }=}$

Valkenburg, P. M., Semetko, H. A. \& De Vreese, C. H (1999) The Effects of News Frames on Readers' Thoughts and Recall. Communication Research, Vol 26, No. 5: 550 - 569.

World Economic Forum (2016) 3 reasons things are looking up for African economies. Retrieved from https://www.weforum.org/agenda/2016/05/what-s-the-future-of-economic-growth-inafrica/ accessed on 30 January, 2018.

Yusha'U, M. J. (2012) Representation of Boko Haram discourses in the British broadsheets. Journal of Arab and Muslim Media Research, Vol. 5, No. 1: 91 - 109. 